\title{
Pandemics and Armed Forces: Which Roles Are Appropriate?
}

\section{John L. Clarke}

George C. Marshall European Center for International Security Studies, https://www.marshallcenter.org

\begin{abstract}
In the current pandemic crisis, the armed forces of many nations are being called upon to provide assistance and support to the civil authorities in an ever-expanding fashion. This article explores the kinds of roles, missions, tasks, and functions that the armed forces are carrying out in this crisis and identifies a number of policy considerations for decision-makers to ponder when they consider tasking the armed forces to provide these services.
\end{abstract}

Keywords: crisis management, defense support to civilian authorities, disaster, law enforcement, capabilities, COVID-19

\section{The Military's Response to Pandemic Disease}

The Covid-19 crisis has caused leaders in all affected countries to turn to their armed forces for support in an ever-expanding range of roles. Armed forces are being tasked to provide capabilities that, in many instances, go beyond what they have provided in past crises. It must be expected that these demands will continue to mount even as the current crisis abates, as the pandemic is expected to remain a top national concern for months to come. This article examines the range of roles that armed forces have taken on within the context of this crisis and places those roles, missions, tasks, and functions within a scheme of six mission sets that comprise the Defense Support to Civil Authority (DSCA) rubric. The article goes on to set forth a half-dozen considerations for decision-makers to contemplate before asking the armed forces to undertake these roles. 
In the current pandemic crisis, many of the tasks inherent in the DSCA rubric have been prominent in the demands by political leaders for armed forces support, such as the provision of essential services (many logistical and medical in nature) as well as some search capabilities and engineering support. For example, armed forces in Italy, Spain, France, and the United States, just to name a few, have built and staffed medical facilities, transported virus patients, delivered food supplies, searched buildings for victims and decontaminated residences and public facilities, such as train stations and airports.

In addition, armed forces organizations have provided mortuary services, including the transportation and cremation of virus victims remains, which, of course, are contaminated. Photos of Italian Army units have shown convoys of trucks loaded with coffins. Soldiers have also provided medical support to overwhelmed facilities. Soldiers have been photographed administering tests for the virus, moving patients within hospitals, and providing basic services, such as changing bedpans and providing meals, all in a contaminated environment. French military aircraft, equipped for medical evacuation, have transported virus patients to less-stressed medical facilities in France.

Of course, military medical facilities and personnel are not optimized for pandemic outbreaks, but rather for battlefield trauma operations. Moreover, the employment of military medical facilities and personnel in support of civilian facilities inevitably impacts on the military's ability to provide medical services to its own forces.

As societies come under increasing-and unrelenting-pressures due to the pandemic crisis, political leaders are increasingly turning to the armed forces in affected nations to provide support for their police and security forces, as well as for stressed medical and public health organizations. The range of roles and tasks that armed forces personnel are being called upon to support is expanding rapidly and will have significant impacts on the ability of those military organizations to perform their principal missions as the coronavirus crisis deepens.

In all western countries, the armed forces have a long and honorable history in supporting the civil authorities in coping with domestic contingencies. For many countries, particularly those in Europe, supporting the civil authority is a principal mission, equal to that of defending the national security; in others, particularly in Africa and Asia, domestic issues are the principal focus of the national armed forces. Thus, the tradition of armed forces support for the civil authority, and in some cases, even supplanting it, is well established. As a result, we see national authorities increasingly relying on military forces to provide for a novel range of public tasks in response to the crisis. Given the trends extant in contemporary societies, it is worth exploring what political leaders, and the societies they lead, are asking soldiers to do and where it may lead, for the demands on those forces will only grow. 


\section{The Missions at Home}

In the domestic context, there are essentially two mission sets: homeland defense and civil support. Homeland defense is the traditional task of defending the population, infrastructure, and sovereignty of a nation against threats arising from outside the state. This may involve such tasks as border defense (as differentiated from border security), air defense, and defense of maritime approaches.

Of course, most military forces in NATO countries were designed for the Cold War mission of defending the European homeland in the event of a Warsaw Pact attack; their legacy organization and equipment bear witness to this. For example, Germany had large numbers of armored forces and great numbers of reserve forces; both have nearly disappeared in the post-Cold War period. What forces remain have often been restructured, for the most part, for deployments abroad in peace support operations roles. Also, their numbers have dwindled. Most NATO countries have active force establishments that are but a fraction of their Cold War strength, which begs the second question: is homeland defense still a core mission? And if so, can European armed forces actually carry it out if so directed? For a while, many European countries still retain relatively large numbers of soldiers on the books; however, they are not necessarily organized, configured, trained, and equipped for modern conventional high-intensity operations.

In addition to homeland defense, NATO military forces have always been heavily involved in the second homeland mission, that of civil support. Civil support tasks are those undertaken in support of civil authority, with responsibility and overall command remaining with that civil authority. These tasks include assistance to local authorities in the event of disasters as well as support to law enforcement authorities for select tasks. It may also include actions taken by the military to restore law, order, and stability in the aftermath of a major catastrophe or an insurrection. Such operations may involve both active and reserve forces, as well as some specialized capabilities, such as airborne radar for border surveillance. In every event, the key is that civilians remain in control.

Indeed, the range of tasks for which armed forces may expect to be called into action has long been broad and continues to expand. Military forces have become, in many instances, a resource of choice for many political leaders faced with intractable (often fiscal) problems, including many not related to national security or humanitarian relief.

Clearly, there are civil security tasks that armies can, should, and must perform. This article is focused on identifying those domestic roles and tasks which are inherent to national armed forces, those that armed forces may be called on to support and those that are candidates for inclusion in this growing list, with particular emphasis on the role of armed forces in providing cybersecurity. But it is worth asking what tasks the army should not perform as well. There are tasks for which military forces, for a variety of reasons, are not suitable. This is not to say that armed forces are incapable of performing them, merely that they are 
not consistent with what we might consider being acceptable civil support tasks. Are there red lines beyond which armed forces ought not to tread?

There appear to be six distinct Defense Support to Civil Authority (DSCA) mission sets for armed forces in civil security, with four having particular utility in pandemic crises. They are:

- $\quad$ Defense Support for Emergencies and Disaster Relief (DSDR)

- Defense Support to Law Enforcement (DSLE)

- Defense Support for Special Events (DSSE)

- Defense Support for Essential Services (DSES)

- Defense Support for Counterinsurgency (DSCI)

- Defense Support for Civil Disturbances (DSCD)

The four with clear applicability for pandemic crises are Defense Support for Emergencies and Disaster Relief (DSDR); for Law Enforcement (DSLE); for Essential Services (DSES) and Civil Disturbances (DSCD). These four will be discussed in detail as to their employment in pandemic crises.

Armed forces in North America and Europe have long carried out these kinds of missions. It is common and expected that in national emergencies the armed forces of a nation would respond and provide support of a robust nature. Soldiers expect to be called upon to assist in these kinds of emergencies and can bring with them unique capabilities, such as the ability to operate in contaminated environments and to provide their own logistics and security. Soldiers can expect increasing calls from civilian authorities for their services. The specific roles, tasks, mission, and functions that military organizations can be expected to fulfill comprise a catalog of requirements that demand a taxonomy which clearly sets forth the categories of expected taskings.

\section{Defense Support for Emergencies and Disaster Relief}

When major emergencies strike, the first responders almost always include soldiers. In the world of complex emergencies, military forces bring a level of capability that is almost always in demand from the very start of the crisis. Military forces can do things more rapidly, and often more comprehensively, than the usually much smaller civilian emergency response elements. Armed forces often have unique capabilities for dealing with specific kinds of emergencies, such as toxic chemical spills, which are often lacking in these other response forces. It is therefore not surprising that many armed forces have response to domestic emergencies and disasters as one of these principal missions. Military forces have been exceptionally active in responding to requests by the civilian leadership for assistance in these kinds of contingencies.

Military forces have a number of characteristics that lend themselves to early, rapid, and effective response to emergencies and disasters. Perhaps the most salient capability that military forces are able to offer civilian leaders in catastrophes is the most elementary: an ability to support oneself. While elementary, 
this capability is often of critical importance, particularly in the early stages of these kinds of catastrophes. The military's ability to self-deploy and sustain itself can be decisive. Military forces have their own logistical arrangements, particularly with respect to transportation, lodging, and subsistence support, as well as their own medical capability. Of great importance is the military's ability to provide for their own security as well as furnishing it to other organizations. The fact that many military units are in a state of readiness also contributes to this ability to respond in a timely fashion. Thus, the military is uniquely able to respond and provide key capabilities in response to emergencies and catastrophes.

Typical tasks for military units in response to emergencies and providing disaster relief involve the provision of essential services to an affected population. In a major catastrophe, life essentials such as water and food, in addition to shelter and medical care, may be adversely affected. The military-with its capability for rapidly bringing relief supplies to an affected area-is often the only organization capable of providing this on the scale necessary to provide relief. Further, military units may be employed to provide manpower-intensive support, such as earthquake search and rescue, flood control, which may involve the filling and installation of sandbag barriers, engineering support, which may include the generating and transportation of energy, running of public utilities and water purification support, as well as the repair of damaged transportation infrastructure, such as bridges and roads. These are capabilities which are not often resident in civilian emergency management organizations in numbers adequate to responding to major disasters.

Other military responses to disasters and emergencies may involve highly specialized capabilities that may not be found at all in civilian organizations. These may include specialized communications capabilities, including linguist support, for providing public information during disasters, mortuary services for properly disposing of human remains, air traffic control and port services, which are often necessary for the provision of disaster relief supplies. Military forces are also capable of providing command and control capacity, which is often critical for the staging and deployment of follow-on support. These facilities are often rendered ineffective in the early stages of a disaster, and many communities lack redundant command and control facilities, which the military can provide.

As we have seen, the armed forces of almost all countries globally have been heavily involved in responding to the Covid-19 emergency. Indeed, the demand for soldiers and the unique capabilities that armed forces possess continues to grow; we can expect that military organizations will continue to be engaged for a long time to come and that the roles that they will play will continue to grow.

\section{Defense Support to Law Enforcement (DSLE)}

Soldiers are not policemen. Nevertheless, military forces have traditionally provided aid to law enforcement agencies - an activity that appears to be growing in importance, particularly in response to pandemic disease requirements. 
Armed forces provide support to law enforcement agencies in two ways: the first is support that helps law enforcers do a better job by providing them with technology, training, or logistical support that enables them to enforce the law more efficiently and effectively. The second kind of support that soldiers provide to police officers is to replace them. This involves having soldiers serve in lieu of police officers, thus allowing law enforcement personnel to perform other tasks.

In the first instance, armed forces, due to their significant inventories of high technology equipment and the training that accompanies it, are able to offer law enforcement agencies access to capabilities that many agencies would typically not be able to use. For example, law enforcement agencies charged with border security are often able to rely upon ground surveillance radars provided by the military. Similarly, the armed forces may put aviation assets, particularly helicopters, at the disposal of law enforcement agencies who have limited air mobility capabilities.

In the field of training, military forces are often able to provide highly specialized training to law enforcement personnel. An example would be the provision of training for handling chemical and biological agents and for operating in a contaminated environment.

Soldiers may also be tasked to provide security for police officers. In the same manner that police are often asked to help provide security for first responders operating in a difficult or insecure environment, soldiers may be called upon to provide a measure of security to law enforcement organizations charged with carrying out law enforcement activities in areas such as city slums and difficult terrain used by organized crime to hide their activities.

In all these DSLE activities, the military must be, and must be seen to be, in support of civil law enforcement authorities. In those instances in which the military provides support for police officers, there is always the danger of law enforcement becoming overly militarized. The military must be very careful to avoid taking over these operations unless that is the express intent.

The second kind of DSLE operation is that when soldiers perform law enforcement functions instead of police officers. They are likely to be times when police forces are stretched to their maximum and request the support of the armed forces to conduct specific law enforcement tasks for a specific period. For example, military forces might replace police in carrying out low-level perimeter security or traffic control functions in support of a major sporting event. Similarly, armed forces might conduct patrols as part of security efforts for protecting critical infrastructure or critical assets.

Military units have also been given responsibility for the protection of some critical infrastructure and other key assets. In France, French soldiers help protect key transportation hubs, tourist attractions such as the Eiffel Tower and some parts of the nuclear energy chain. In Italy, the armed forces now provide external security for diplomatic representations in Rome, relieving the police of this task. They also conduct joint patrols with police in certain parts of some Italian cities. These operations, which involve the presence of uniformed and armed 
soldiers on the streets of European cities in what we might call presence operations, have also increased in recent years, particularly in response to threats of terror.

DSLE tasks pose a number of challenges for both the military and the civilian leadership, which directs them. Asking the armed forces to provide these functions runs the risk of militarizing law enforcement. This trend towards beefing up police forces can be exacerbated when soldiers carry out police tasks.

The legal issues are also contentious. Some European countries, notably Germany, prohibit employing soldiers on DSLE tasks. Others, such as France and Italy, have an active history of doing so. However, the legal hurdles are significant. The hazards of authorizing military personnel to use force, particularly deadly force, in support of law enforcement activities are hazardous. Soldiers are trained to use force in the first, not the last instance-the opposite of police training. Arrest authority is another area fraught with problems. In some DSLE operations, it may be necessary to authorize solders to arrest and detain suspects; but doing so may open soldiers up to legal liability unless their authority is clearly established in law.

Finally, it should be noted that the presence of militarized police forces, such as the French Gendarmerie, Italian Carabinieri, and Spanish Guardia Civil, mitigates the need for some DSLE activities in some European states. Often, these hybrid forces are able to provide many of the requirements of DSLE. The versatility of these forces lends itself to a wide range of DSCA tasks.

Armed forces have been asked to take on numerous DSLE tasks in response to the current crisis. Increasingly, soldiers are relieving overburdened police forces in the conduct of lower-level law enforcement tasks, such as traffic control and security presence outside of major cities, as well as reinforcing border security forces. As the situation develops, it may be necessary for the armed forces in some countries to take on more security tasks, such as prison security and food supply security.

\section{Defense Support for Essential Services (DSES)}

Soldiers have often been called upon to provide services to the public when, for a variety of reasons, those services cannot be provided by others or because the military has traditionally provided those services. Civil authorities in many countries have not hesitated to call upon their military forces to provide help in order to sustain services which they view as essential.

By essential services we mean those services whose execution is so critical to the functioning of the state that they must be performed or the state and its citizens will suffer, sometimes grievously. Examples of an essential service would be those associated with the emergency response: law enforcement, fire, and ambulance services. As no clear definition exists, states have come to freely characterize services as essential, often because of the potential political consequences of their failure to provide them. In some instances, these services have 
been normally provided by other elements of the state or by commercial providers.

The requirement to provide such services may come about for a variety of reasons. They may be required because a major disaster has rendered their regular provider incapable of doing so, or industrial action or strike might have caused a cessation of a particular service. Other essential services, such as explosive ordnance disposal, the military has traditionally provided to a state. Lastly, specialized, one-time services may be necessary when no existing institution of the state can manage with its own resources.

The list of essential services that military forces have provided to civil authorities is extensive. DSES operations may require the military to provide support ranging from trash collection to acting on behalf of the government in extreme circumstances. In this latter instance the military, because of its inherent capability for command and control, must be prepared to exercise continuity of government (COG) and continuity of operations (COO) services in the event of a breakdown in a government's ability to function, for example due to a major natural catastrophe or attack.

Other DSES tasks may include search and rescue (SAR) operations. In many countries, such as Finland, national SAR capabilities are resident in the armed forces. Military forces often have the requisite equipment, such as helicopters and the necessary training to accomplish this task. Other types of DSES tasks of this nature might include the establishment and maintenance of asylums camps in the event of mass immigration due to conflict or disasters in neighboring countries.

By far, the most common reason for the employment of armed forces in DSES operations is in response to industrial action. Military forces have provided essential services such as fire response in response to a strike by firefighters on numerous occasions, including several times in the last two decades in the UK and, more recently, in Greece in 2010.

Armed forces have also provided DSES assistance in response to strikes by transportation workers in France in the 1980s, by fuel transportation workers in the UK in 2000 and Greece in 2010, as well as providing support to law enforcement in response to strikes by prison employees in several instances.

This mission set includes instances where the military is tasked to provide services that are deemed essential for security or other reasons, such as public health. Examples would include the provision of air traffic control services in the event of a strike or providing support services in the wake of an outbreak of pandemic disease, as is the current case with the Covid-19 global emergency. As those who work in critical sectors such as transportation, fire safety, and ambulance services become incapacitated by the disease, it is logical that the armed forces may be asked to step in to provide such services. Similarly, as states begin to recover from the ravages of the disease, the armed forces are likely to play increased roles in decontaminating public areas and monitoring of populations for health risks. 


\section{Defense Support for Civil Disturbances (DSCD)}

States may, as a consequence of war, insurrection, or natural calamity, find it necessary to impose law, order, and stability through means other than regular law enforcement. In times of great unrest and disorder, civilian leadership may find that its law enforcement bodies are overwhelmed and that it is necessary to call upon the military to help restore and maintain order. Defense support in times of a great crisis may require the imposition of martial law. Martial law refers to the necessity to engage the armed forces to carry out essential law enforcement functions, as well as a host of other essential services. Most NATO countries have not experienced martial law in the post-war period, even those that have had military governments, which governed according to the rule of then-existing law. Martial law goes well beyond this, with soldiers carrying out tasks intended for police officials.

While unlikely, it might become necessary to impose martial law in the aftermath of a significant natural or industrial catastrophe, such as a pandemic disease emergency or in response to a major terrorist attack with a weapon of mass destruction. In these instances, there might be a general breakdown of law, order, and stability, rendering existing law enforcement organizations incapable of carrying out their duties. It would then become necessary for the armed forces to assert control, usually through a declaration of martial law. While this concept is not embedded in many constitutions, the basic structure is usually present, particularly in those countries with militarized police forces.

As noted, in these instances of a complete breakdown, military forces may well be required to perform a broad range of essential functions. Food, water, lodging, clothing - the list may appear endless. Often, military forces, as previously described, are the only organizations able to respond because of their inherent logistics capability and ability to self-deploy.

\section{Criteria for Decision Makers}

Logical, straightforward criteria are required for effectively evaluating situations in which the armed forces might be used in domestic contingencies, particularly concerning pandemic disease emergencies. Six considerations ought to be examined in vetting requests for assistance. Of course, it is recognized that, in some countries and at some times, these criteria may be overlooked or ignored, if the threat of catastrophe disease facing a country is significant enough.

The first and foremost consideration is that of legality. Each request should be evaluated in terms of compliance with the laws of that state and its international commitments. Is the request, and the manner in which it has been made, compliant with the laws of the land, in particular with the constitution and those laws which have been established to govern the employment of the armed forces? While many states, such as Germany and the United States, have laws restricting the domestic deployment of armed forces, others, notably France, do not have such restrictions. There may also be exceptional events, such as major 
catastrophes or outbreaks of highly contagious diseases, resulting in the breakdown of law and order, which may require capabilities that only the military may be able to provide, even if that employment contravenes the legal construct. While this has not yet been the case with the Covid-19 crisis, it cannot be excluded, particularly as unemployment rises and access to foodstuffs becomes difficult.

The second criterion is that of lethality. This criterion considers the issue of whether the military may be required, as part of the provision of support, to employ force, particularly deadly force. The issue of the use of force in domestic contingencies is fraught with danger, as discussed previously in this article. Lethality also considers the possibility that forces may be used against those military forces engaged in DSCA efforts. The potential for the employment of force may require that the military be provided with special equipment and training and be issued appropriate rules of engagement that govern the use of force. As a general rule, military forces in support of civil authorities should always seek to avoid the use of deadly force except in extreme situations. Nevertheless, circumstances may require to engage in potentially lethal activities in self-defense or to prevent greater harm to the population, as might be the case in an outbreak of a highly contagious and deadly epidemic. If it were to become necessary to enforce quarantine orders, the situation might arise where it becomes necessary to employ force, with all of the implications of such a decision, as noted in the discussion of DSCD.

Risk is the third of the criteria governing the employment of armed forces in DSCA. While similar to lethality, risk is more concerned with the safety of the soldiers on DSCA missions. In particular, it seeks to evaluate whether there is enhanced risk to the safety and health of those soldiers who, in the process of performing a task, may be exposed to harmful agents, such as biological or chemical toxins or be required to undertake hazardous acts, such as rescuing civilian personnel or extinguishing large fires. For example, support for civil authorities in the current Covid-19 crisis may expose soldiers to the virus itself; likewise, decontaminating an area with radiation or chemical contamination poses risks to the force given this task. Risk further seeks to determine the long term effects on the force, both physical and psychological, of carrying out tasks which may be disagreeable, such as the collection and disposition of large numbers of fatal casualties pursuant to a major disaster or pandemic disease. Putting soldiers on the streets in uniform can provide for a sense of increased security, but it may render them more vulnerable to attack.

Readiness is the fourth criterion that should govern the process of considering the deployment of military forces in DSCA missions. Armed forces exist to defend the nation against external threats; to the extent that they are engaged in DSCA tasks, they may not be available to carry out their primary missions of national defense, as there is always an opportunity cost to pay. For those DSCA tasks which have little relationship to military functions, such as, say, trash collection, and which may be of long duration there may be a degree of erosion of 
primary military skills, such as tank gunnery or artillery fire support, which will require time, effort and resources to recover. Readiness also seeks to measure the opportunity costs associated with the military's ability to perform other military and DSCA functions. If the army, or parts of it, is engaged in a DSCA task, it may not be available to perform other tasks in a reasonable amount of time. In the Covid-19 emergency, we have seen instances where the readiness of military units or maritime forces have been impacted negatively. The ability of the armed forces to recruit and train new members is also likely to be negatively impacted in a viral contamination crisis.

The fifth consideration for evaluating a request is that of cost. The issue of who pays for the military's involvement in DSCA is of great, and increasing, importance. Many DSCA missions and tasks can involve a considerable expenditure of resources. In particular, when the military provides disaster relief support to civil authorities in the aftermath of a major disaster, this may involve the expenditure of significant amounts of money for supplies and transportation, in addition to the personnel costs involved. In Europe, these costs are, in some cases, born by the ministry of defense itself. In others, the ministry of defense expects to be reimbursed for some or all of those costs by the ministry or agency to which the assistance is being provided. These considerations should be laid out well in advance of the need for the military's support.

In those instances, in which the ministry of defense is expected to pay for the support it provides, this criterion should also include an evaluation of the impact on the appropriations under which the military functions. There may also be circumstances under which the military receives reimbursement for services and materials rendered, which it may use for purposes other than a reconstitution of the same. In these cases, the military may well choose to use the reimbursement to acquire the equipment it lacks or to provide training that is needed. In a national emergency involving viral contamination, the issue of cost may be initially moot, but it is sure to resurface as the crisis drags on.

The last criterion is that of appropriateness. This criterion seeks to answer the question of whether it is right, or seen by the public to be right, for the military to carry out a DSCA task. This issue is connected to the larger issue of the image of the armed forces. Appropriateness is also concerned with the question of whether it is in the interest of the ministry of defense to conduct the task. In cases of disaster relief, the military almost always will answer in the affirmative. However, there are instances, particularly those involving the potential use of lethal force against citizens, which may be viewed by the military as inappropriate and detrimental to the image of the military.

While these six criteria are those which most often govern the military's evaluation of a request for assistance, there may be others, such as the consideration of whether the military has the capacity, in terms of numbers of soldiers or their training, to provide assistance. The military, because of deployments or other engagements, may simply lack the surge capability to provide support. 
One further consideration is the issue of unique capability. As a general rule, the military should be asked to provide DSCA support only when the military has a unique capability, not resident in type or required quantity in other agencies. A typical example involves the provision of decontamination support. Most other agencies lack the military's capability for decontaminating chemical or biological contamination; therefore, it may be appropriate to request military support in the event of such an incident, because no other agency can provide this support.

\section{Conclusion}

It should be clear that the armed forces represent a massive capacity for decision-makers to consider when confronted by pandemic disease crises. The armed forces have a range of capabilities, many of them unique, which can make a critical difference in the ability of a state to survive such a crisis as we are now seeing with respect to Covid-19. The increasing trend to continue to add to the non-military roles of the armed forces, while of great importance, is not without costs, which, at some point, must be considered.

It seems evident that we are likely to see more soldiers on the streets, carrying out tasks that are critical in nature. We should applaud the ability, and the readiness, of soldiers to do so. But these contributions should not be forgotten when the crisis has passed.

\section{Disclaimer}

The views expressed are solely those of the author and do not represent official views of the PfP Consortium of Defense Academies and Security Studies Institutes, participating organizations, or the Consortium's editors.

\section{Acknowledgment}

Connections: The Quarterly Journal, Vol. 19, 2020 is supported by the United States government.

\section{About the Author}

Dr. John L. Clarke is Professor at the Marshall Center in Garmisch, Germany. Dr. Clarke is recognized as a leading expert on the role of military forces in Homeland Security, with a focus on cybersecurity issues. He has developed and taught numerous courses on homeland security, crisis management, and stability operations, as well as developing scenario-based exercises and simulations. He led a major research project on European Approaches to Homeland Security. He has published several books on the role of armed forces in domestic contingencies, including What Should Armies Do? Armed Forces in Civil Security and Armies in Homeland Security: American and European Perspectives. He most recently served as the Senior Eisenhower Research Fellow of the NATO Defence College in Rome in 2016-2017, focusing on cybersecurity operation. 